\title{
Geologiske interesseområder - Århus Amts nye hjemmeside om geologi
}

Af geologerne Erling Fuglsang Nielsen, Århus Amt, Tove Stockmarr, Geo-Formidling og afdelingsleder Richard Thomsen, Århus Amt

\section{Århus Amt har i løbet af 2004 og} 2005 som led i den generelle regionplansrevision sat fokus på amtets geologiske interesseområder. I alt 77 områder (med tilhørende underlokaliteter) er udpeget som områder, der har særlige geologiske og landskabelige værdier. Disse områder er nu beskrevet og sammenstillet i 77 beskrivelser, der ligger frit tilgængeligt på amtets hjemmeside.

Besøg: http://www.aaa.dk/aaa/nm-geologiske-interesseomraader.htm og tag på rundrejse i amtets geologi. En samling af interesser, der dels omfatter velafgrænsede lokaliteter såsom kystklinter og råstofgrave, dels større sammenhængende områder. Alle interesseområder er udpeget og beskrevet på baggrund af en helhedsvurdering og rummer geomorfologiske og landskabelige værdier, som tilsammen lader området fremstå med bevaringsværdig karakter. Mange af amtets interesseområder har tilmed status som nationale og internationale geologiske interesseområder (figuren til højre).

Som supplement til Århus Amts Regionplan 2005 er der foretaget en beskrivelse, vurdering og revision af regionplanens geologiske og landskabelige interesseområder. Projektets intention er at bevare og beskytte landskabsformer, profiler, m.v. der særligt tydeligt afspejler landskabets opbygning og de geologiske processer. Inden for områder af særlig geologisk interesse er hensynet til geologien naturligvis tillagt særligt stor vægt.

Fokus på de geologiske interesser I Århus Amt har det i en årrække været Natur- og Miljøkontorets Grundvandsafdeling, der har skullet varetage amtets geologiske interesser. De geologiske interesser er vist på amtets Regionplanbilag; men afdelingen har længe haft et ønske om at synliggøre udgangspunktet for de afgørelser, der træffes, når der fx gives afslag på en konkret ansøgning om at placere et teknisk anlæg et sted. Efterhånden indså afdelingen, at man simpelthen ikke havde tid til at udføre arbejdet selv. I stedet valgte man at finde en kon-

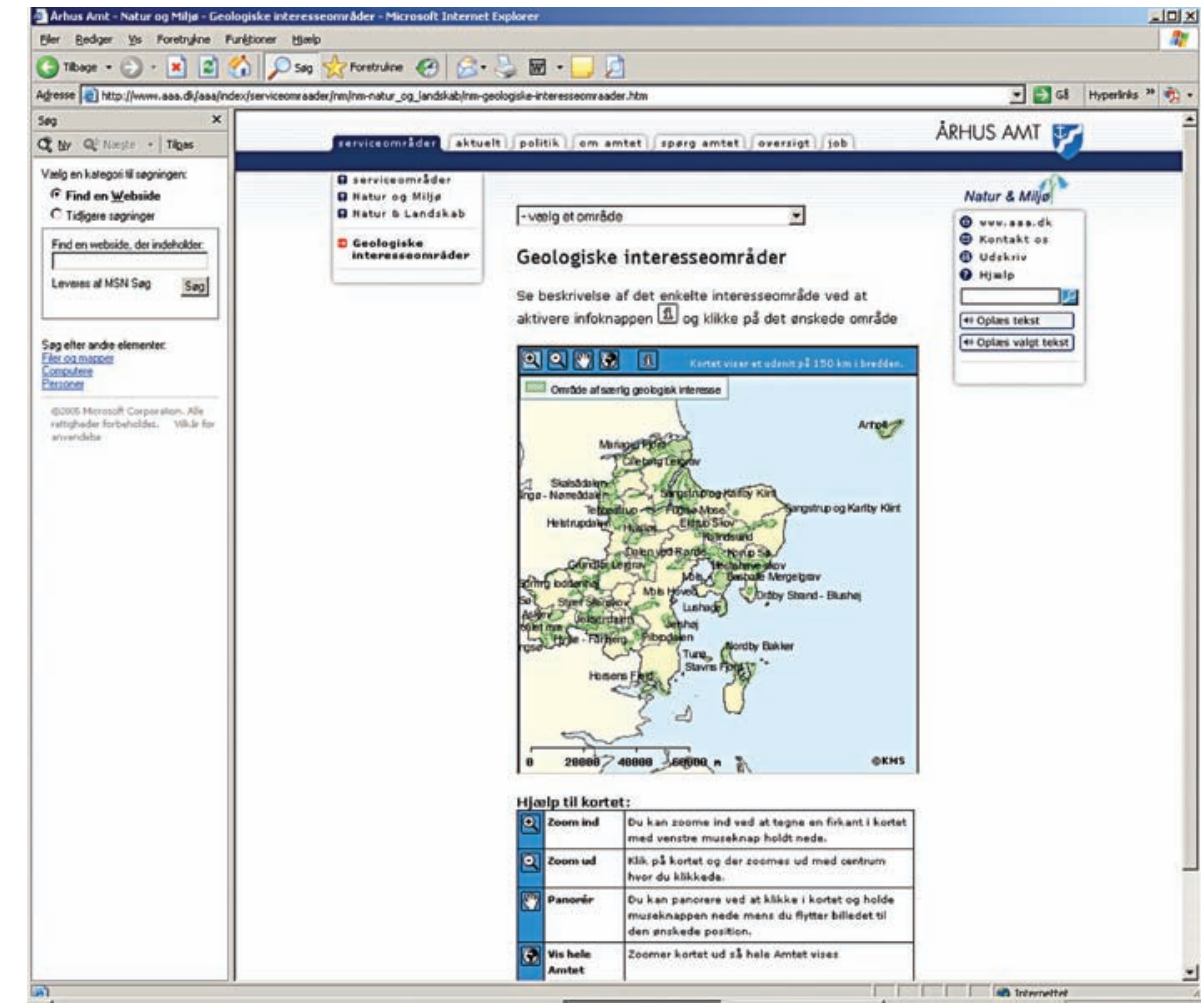

Fra websidens prcesentationsvindue: Oversigtskortet viser de geologiske interesseområder i Århus Amt. Ved at gå ind på et specifikt sted på kortet, kan man dels forstørre udvalgte dele af dette, dels få en beskrivelse af de geologisk interessante ting på stedet.

sulent, der kunne tage sig af den konkrete beskrivelse af lokaliteterne - herunder besøg og fotografering af disse.

Grundvandsafdelingen valgte firmaet Geo-Formidling til dette, og vi synes i Grundvandsafdelingen, at det er blevet et meget fint resultat. Resultatet, der nu er frit tilgængeligt, kan også benyttes af entreprenører, landmænd, kommunesagsbehandlere og andre interesserede, der blot vil ud at gå en tur i vort smukke amt.

\section{Udpegningen/vurderingen}

De konkrete vurderinger, der danner grundlag for revisionen af amtets geologiske interesseområder, bygger på såvel en kvantitativ som en kvalitativ analyse med vægt på såvel morfologiske detaljer som helhedsvurderinger af større sammenhængende områder.

De i Regionplan 2005 udpegede områder bygger på såvel feltbesøg som på kortbladsanalyser sammenholdt med eksisterende videnskabelige beskrivelser. Ved feltbesøg er alle områder vurderet ud fra helhedsindtryk, hvori såvel landskabets overordnede morfologi som dets enkeltelementer og geologiske dannelse spiller en afgørende rolle i sammenhæng med æstetiske værdier. På 


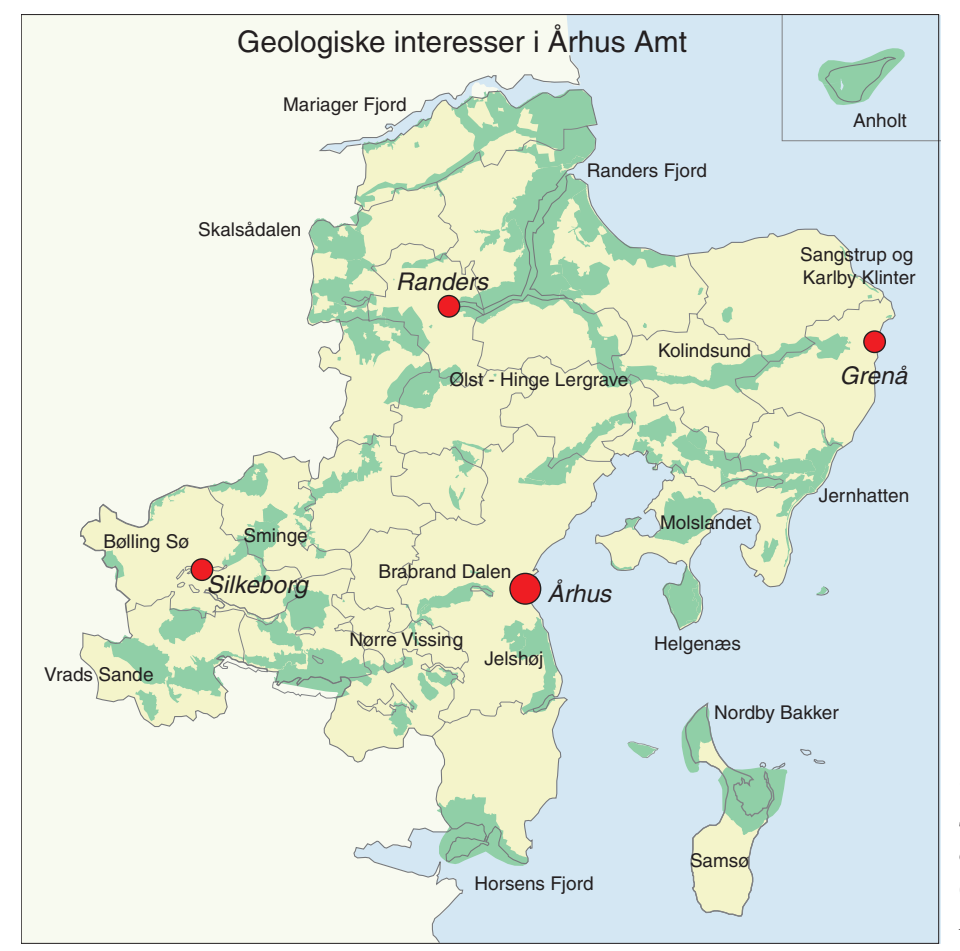

Geologiske og landskabelige interesseområder i Århus Amt. (Grafik: Jette Brøndum, Århus Amt)

velafgrænsede lokaliteter såsom kyststrækninger og råstofgrave er der især fokuseret på stratigrafiske og strukturelle informationer.

Eksempel på geologisk interesseområde En enkelt post er eksempelvis opbygget efter følgende skabelon:

\author{
- overskrift, geografisk placering og faglig \\ beskrivelse \\ - værdi \\ -tilgængelighed \\ - trusler samt forslag til pleje \\ - eksisterende foldere, udstillinger, links, m.m. \\ - administrative forhold \\ -litteraturhenvisninger
}

Da mange af amtets interesseområder danner baggrund for betydelige geologiske afhandlinger for både holocæn, pleistocæn, palæogen og neogen stratigrafi, er det af og til prioriteret at vedhæfte yderligere beskrivelser som pdf-fil.

I den nordlige del af amtet træder kridttidsaflejringer også frem.

Som eksempel på et af interesseområderne er Horsens Fjord beskrevet i næste artikel.

Formål med Regionplanbestemmelsen Hensigten med bestemmelsen er at sikre, at der tages hensyn til de geologiske interesser ved planlægning af større bygge- og anlægsarbejder, skovrejsning, råstofindvinding, m.v Derved sikres mulighederne for at opleve, forske og undervise i de geologiske processer.

Orientering og dermed gennemsigtighed er set som en central del af befolkningens mulighed for at kunne forstå de afgørelser, som myndighederne træffer. Herudover sik- rer en internetbaseret beskrivelse, at også almindeligt naturinteresserede kan få inspiration til oplevelsen af de geologiske interesseområder.

\section{Projekt med mange muligheder}

I løbet af arbejdet har vi haft veldefinerede målgrupper for øje. Det har således været vores intention, at en bred målgruppe bestående af de af amtets egne sagsbehandlere, der ikke arbejder med geologi i det daglige, kan blive påvirket af de allerede i Regionplan 1997 og 2001 foretagne udpegninger af interesseområderne. Endnu vigtigere er det, at kommunale sagsbehandlere og interesserede borgere, men også borgere, hvis interesser vil blive påvirket af amtets afgørelser, vil tage projektet til sig som et hurtigt og effektivt opslagsværk og hjælpemiddel og nu kan anvende internetsidens geologiske beskrivelser.

Idet projektet er IT-baseret, er det selvsagt muligt at foretage ajourføringer, m.m. Dette gør projektet til et hurtigt og effektivt redskab, der kan indgå i såvel nuværende som fremtidige sagsbehandlinger. Afslutningsvis er det endvidere vort håb, at også fx studerende eller rådgivende ingeniørselskaber vil kunne finde anvendelse af projektet og tage det til sig.

\section{Tak til}

Ole Bjørslev Nielsen og Christian Kronborg (begge Aarhus Universitet) samt Gunnar Larsen, Fyns Amt for deres medvirken ved gennemgang af lokalitetsbeskrivelser. Ansvar for eventuelle fejl og mangler påhviler naturligvis udelukkende Århus Amts Grundvandsafdeling, der i øvrigt gerne modtager forslag til rettelser og tilføjelser m.m. til de viste lokalitetsbeskrivelser.

\section{Geologisk tidsskala}

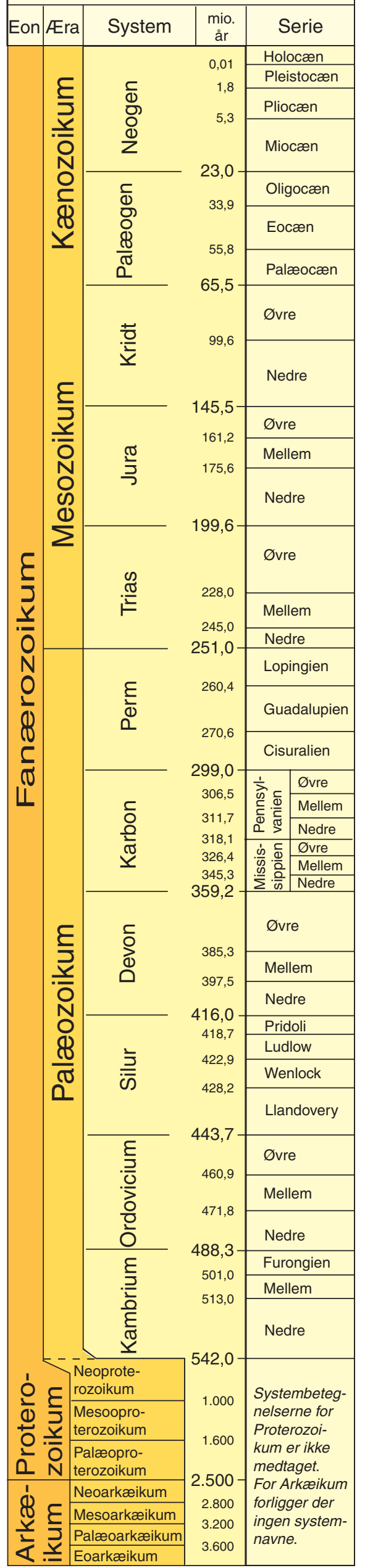

